\title{
QUANTITATIVE HISTOCHEMISTRY OF THE NEPHRON. V. ALKALINE PHOSPHATASE AND LACTIC DEHYDROGENASE ACTIVITIES IN LUPUS NEPHRITIS *
}

\author{
By VICTOR E. POLLAK, $\dagger$ SJOERD L. BONTING, ROBERT C. MUEHRCKE \\ AND ROBERT M. KARK
}

\begin{abstract}
(From the Departments of Biological Chemistry and Medicine, University of Illinois College of Medicine, and Departments of Medicine, Presbyterian-St. Luke's Hospital, Cook County Hospital, and Research and Educational Hospitals, Chicago, Ill.)
\end{abstract}

(Submitted for publication March 25, 1960; accepted April 22, 1960)

The natural history and histological development of lupus nephritis have been studied in detail in our laboratory $(1,2)$. The glomeruli were more severely involved histologically than were the tubules at all stages of development of lupus nephritis. In the early stages (lupus glomerulitis) the histological abnormalities were confined to the glomeruli. Only when the glomerular involvement became considerably more severe was there histological evidence of tubular degeneration and interstitial fibrosis and inflammation (lupus glomerulonephritis). Even in lupus glomerulonephritis, histological abnormalities of the tubules and interstitial tissue were considerably less severe than in other types of glomerulonephritis. These histological observations were reflected functionally; in that ability to concentrate the urine and to excrete phenolsulfonphthalein were preserved until comparatively late in the disease.

In a previous paper of this series (3) the alkaline phosphatase and lactic dehydrogenase (LDH) activities of individual anatomical and functional units of the nephron were reported for healthy kidneys, and for a variety of diseases which affect primarily the renal tubule, i.e., diseases associated with a functional imbalance between tubules and glomeruli. In this paper, the results of assays of the activities of these two enzymes will be reported for lupus nephritis-a disease in which there appears to be histological and functional imbalance between glomeruli and tubules.

\footnotetext{
* Supported by a grant from the Surgeon General's Office, U. S. Army (Contract no. DA-49-007-MD-637). $\dagger$ Established Investigator, American Heart Association, supported by the Illinois Heart Association.
}

\section{MATERIAL AND METHODS}

\section{Clinical material}

A total of 19 kidney specimens was analyzed for alkaline phosphatase and $\mathrm{LDH}$ activity. Eighteen specimens were taken by percutaneous renal biopsy (4), and 1 specimen was obtained at autopsy. Nine specimens were analyzed on 4 patients, studied serially, and a biopsy and autopsy specimen were taken from 1 patient.

An independent and detailed histological analysis was made on each specimen according to the methods previously described (1). On the basis of this analysis the specimens assayed for enzyme activity were divided into the following groups.

1. Lupus glomerulitis (5 biopsies). This term was used to indicate a proliferative and/or membranous lesion of the glomerular tufts in the absence of significant tubular damage or changes in the interstitial tissue (1). The glomeruli were involved to a mild degree in all five.

2. Lupus glomerulonephritis (12 biopsies). This term was used to indicate a more severe membranous and/or proliferative lesion of the glomeruli, associated with definite tubular and interstitial tissue changes (1). The kidneys with lupus glomerulonephritis were subdivided into two groups as shown below.

a) Active lupus glomerulonephritis (5 biopsies). Definite morphologic evidence of activity was observed in the glomerular lesions, i.e., one or more of the following histological features was prominent: local necrosis, karyorrhexis, hematoxyphil bodies, fibrinoid "hyaline" thrombi, and "wire loops" $(1,2)$. Two of the five patients were receiving prednisone (15 and $20 \mathrm{mg}$ daily) when the biopsy was taken; the other three had not been treated.

b) Healed or healing lupus glomerulonephritis (7.biopsies). Thickening of the glomerular basement membrane was the predominant lesion found in these biopsies, all or most of the active lesions present in previous biopsies from the same patients having disappeared. The abnormalities found in the tubules and interstitial tissue were similar to or less severe than those found in active lupus glomerulonephritis (2). All the patients had been treated with large doses of prednisone (40 to $60 \mathrm{mg}$ 
daily) for at least 6 months before the renal biopsies were taken (2).

One biopsy and an autopsy specimen from a single patient were considered separately because, in addition to healing lupus glomerulonephritis, there was partial occlusion of both renal arteries with consequent ischemic changes in the kidneys.

\section{Enzyme assays}

The techniques for handling the tissues and for dissection and weighing of the individual units of the nephron have been described (5). The dissected fragments were assayed for alkaline phosphatase activity and for $\mathrm{LDH}$ activity, under conditions found to be optimal for the human kidney $(5,6)$. Results were expressed in moles of substrate split or moles of DPNH oxidized per hour at $37^{\circ} \mathrm{C}$ per kilogram dry weight of tissue ( $\mathrm{MKH}$ units).

\section{Glomerular weight and density}

In the course of dissecting and weighing glomeruli for enzyme assay we observed that glomeruli from kidneys with lupus nephritis appeared to be both larger and heavier than glomeruli from normal kidneys. A statistical comparison was therefore made of the weights recorded on 130 glomeruli from normal adult kidneys and 234 glomeruli from kidneys involved with lupus nephritis. In addition, the diameters of the glomeruli from each specimen were measured on the stained control sections, using a microscope with a projection viewer. Two measurements were made at right angles to each other on each glomerulus, to obtain an average diameter. Ten glo- meruli from each kidney were measured to give an average glomerular diameter for each kidney. The segments of glomeruli which were weighed had been dissected out from $16 \mu$ sections and all were spherical segments close to the meridians of the tufts. The polar segments and those near the poles were specifically excluded (the terms "pole" and "meridian" refer to the plane of the section). The ratio of glomerular weight to the square of glomerular diameter was calculated as an index of the density of the glomeruli.

\section{RESULTS}

The results of assays for alkaline phosphatase and $\mathrm{LDH}$ activities are given in Tables I and II.

Alkaline phosphatase activity was within normal limits in the glomeruli of patients with lupus nephritis (Table I). However, the alkaline phosphatase activity was considerably decreased in the proximal convolutions $(t=7.3, \mathrm{p}=<0.001)$ and in the distal convolutions $(t=6.36, \mathrm{p}=<0.001)$. These differences were found both in lupus glomerulonephritis (active and healing) and in lupus glomerulitis, in which the tubules were normal histologically.

LDH activity in lupus nephritis was not significantly different from that found in healthy kidneys (Table II), except in the case of the proximal convolutions in which the activity was slightly higher $(t=2.82, \mathrm{p}=<0.02)$. However,

TABLE I

Alkaline phosphatase activity in the anatomical units of nephrons from healthy kidneys and from kidneys of patients with lupus nephritis (expressed in moles of substrate split per kilogram dry weight of tissue per hour at $37^{\circ}$ C) ${ }^{*}$

\begin{tabular}{|c|c|c|c|c|c|}
\hline \multirow[b]{2}{*}{ Structure analyzed } & \multirow{2}{*}{$\begin{array}{l}\text { Healthy adult } \\
\text { kidneys } \\
\sigma \dagger\end{array}$} & \multirow{2}{*}{$\begin{array}{l}\text { Lupus } \\
\text { glomerulitis }\end{array}$} & \multicolumn{2}{|c|}{ Lupus glomerulonephritis } & \multirow{2}{*}{$\begin{array}{l}\text { All lupus } \\
\text { nephritis } \\
14\end{array}$} \\
\hline & & & $\underset{5}{\text { Active }}$ & $\underset{7}{\text { Healing }}$ & \\
\hline Glomeruli & $\frac{0.48 \pm 0.17}{5}$ & $\begin{array}{l}0.46 \pm 0.15 \\
2\end{array}$ & $\frac{0.50 \pm 0.27}{5}$ & $\underset{7}{0.54} \frac{ \pm 0.31}{[41]}$ & $\frac{0.51 \pm 0.25}{14}$ \\
\hline Proximal convolutions & $\frac{5.70 \pm 0.90}{5} \frac{[40]}{[40}$ & $\frac{1.98 \pm 0.33}{2} \frac{16]}{[16]}$ & $\underset{5}{2.41 \pm 0.62}$ & $\underset{7}{2.61} \underset{[62]}{ \pm 0.89}$ & $\begin{array}{l}2.45 \pm 0.72 \\
14[124]\end{array}$ \\
\hline Distal convolutions & $\begin{array}{c}2.70 \pm 0.50 \\
6[40]\end{array}$ & $\begin{array}{c}1.05 \pm 0.48 \\
2\end{array}$ & $\frac{1.05 \pm 0.69}{5} \frac{[21]}{[21]}$ & $\underset{7}{1.17} \frac{ \pm 0.55}{[35]}$ & $\begin{array}{c}1.11 \pm 0.54 \\
14\end{array}$ \\
\hline Degenerated convolutions & & & $\begin{array}{l}4.80 \\
{[4]}\end{array}$ & $\underset{2}{2.12} \stackrel{ \pm 0.65}{[11]}$ & $\underset{3}{3.01} \underset{[15]}{[1.62}$ \\
\hline Medullary rays & $\begin{array}{cc}2.84 \\
1 & {[9]}\end{array}$ & $\underset{2}{1.15 \pm 0.08}$ & $\frac{1.05 \pm 0.94}{2}$ & $\underset{6}{2.19} \frac{1.02}{[28]}$ & $\begin{array}{l}1.75 \pm 1.01 \\
10\end{array}$ \\
\hline $\begin{array}{l}\text { Medulla (outer and inner } \\
\text { medullary zones) }\end{array}$ & $\begin{array}{l}0.80 \pm 0.20 \\
2[11]\end{array}$ & & $\frac{0.50 \pm 0.13}{2}$ & $\underset{2}{0.94} \stackrel{ \pm 0.45}{[31]}$ & $\underset{4}{0.72} \underset{[55]}{[0.37}$ \\
\hline Papilla & $\underset{2}{1.70 \pm 0.89}$ & & $\begin{array}{l}0.44 \\
{[7]}\end{array}$ & $\begin{array}{c}0.77 \\
1 \quad[7]\end{array}$ & $\underset{2}{0.61} \stackrel{0.21}{[14]}$ \\
\hline Small artery & $\underset{5}{1.20 \pm 0.70}$ & $\begin{array}{c}0.80 \\
1 \quad[1]\end{array}$ & $\frac{0.61 \pm 0.48}{4}$ & $\underset{6}{0.42 \pm 0.26}$ & $\begin{array}{c}0.52 \pm 0.35 \\
11\end{array}$ \\
\hline
\end{tabular}

* Mean values and standard deviations are given for the averages of each kidney analyzed. Total number of tissue fragments analyzed is given in brackets.

$\dagger$ Number of kidneys analyzed in each group is shown in italics. 
TABLE II

Lactic dehydrogenase activity in the anatomical units of nephrons from healthy kidneys and from kidneys of patients with lupus nephritis (expressed in moles of DPNH oxidized per kilogram dry weight of tissue per hour at $37^{\circ} \mathrm{C}$ ) *

\begin{tabular}{|c|c|c|c|c|c|}
\hline \multirow[b]{2}{*}{ Structure analyzed } & \multirow{2}{*}{$\begin{array}{c}\text { Healthy adult } \\
\text { kidneys } \\
7 \dagger\end{array}$} & \multirow{2}{*}{$\underset{4}{\text { Lupus }}$} & \multicolumn{2}{|c|}{ Lupus glomerulonephritis } & \multirow{2}{*}{$\begin{array}{l}\text { All lupus } \\
\text { nephritis } \\
14\end{array}$} \\
\hline & & & $\underset{4}{\text { Active }}$ & $\underset{7}{\text { Healing }}$ & \\
\hline Glomeruli & $\underset{6}{108} \underset{[46]}{2}$ & $\frac{84}{4} \stackrel{12}{[26]}$ & $\begin{array}{c}129 \\
4\end{array}$ & $\begin{array}{c}136 \\
7\end{array}$ & $\begin{array}{l}120 \pm 37 \\
15\end{array}$ \\
\hline Proximal convolutions & $\underset{7}{257} \stackrel{ \pm}{[55]}$ & $\underset{4}{207} \stackrel{ \pm}{[35]}$ & ${ }_{4}^{352}=30$ & $\frac{364}{7} \stackrel{ \pm}{[48]}$ & $\begin{array}{c}319 \pm 86 \\
15\end{array}$ \\
\hline Distal convolutions & $\underset{7}{256} \underset{[49]}{ \pm}$ & $\begin{array}{c}225 \pm 62 \\
4\end{array}$ & $\begin{array}{c}338 \pm 63 \\
4\end{array}$ & $\underset{6}{374} \stackrel{ \pm}{ \pm} 128$ & $\frac{321}{14} \pm 114$ \\
\hline Degenerated convolutions & & & $\begin{array}{c}294 \pm 30 \\
2[9]\end{array}$ & $\begin{array}{c}313 \pm 167 \\
4\end{array}$ & $\begin{array}{r}306 \pm 162 \\
6\end{array}$ \\
\hline Medullary rays & $\begin{array}{cc}231 \\
3\end{array}$ & $\frac{204}{4} \stackrel{36}{[27]}$ & $\underset{2}{312} \stackrel{3}{[13]}$ & $\frac{320}{5} \underset{[32]}{ \pm}$ & $\begin{array}{l}276 \pm 90 \\
11\end{array}$ \\
\hline $\begin{array}{l}\text { Medulla (outer and inner } \\
\text { medullary zones) }\end{array}$ & $\begin{array}{c}165 \pm 21 \\
3[22]\end{array}$ & & $1^{212}[12]$ & $\frac{239}{2} \underset{[29]}{[29}$ & $\begin{array}{c}230 \pm 17 \\
3\end{array}$ \\
\hline Papilla & $\begin{array}{c}175 \pm 82 \\
3[8]\end{array}$ & & $\begin{array}{c}130 \\
15]\end{array}$ & $\begin{array}{l}225 \\
16]\end{array}$ & $\underset{2}{178} \pm 67$ \\
\hline Small artery & $\underset{6}{131} \stackrel{ \pm}{[31]}$ & $3^{45} \pm 38$ & $\begin{array}{c}171 \pm 13 \\
2\end{array}$ & $\begin{array}{c}100 \\
6 \\
{[30]}\end{array}$ & $\begin{array}{r}98 \pm 58 \\
11 \quad[61]\end{array}$ \\
\hline
\end{tabular}

* Mean values and standard deviations are given for the averages of each kidney analyzed. Total number of tissue fragments analyzed is given in brackets.

$\dagger$ Number of kidneys analyzed in each group is shown in italics.

significant differences were evident when the kidneys with lupus nephritis were subdivided, on the basis of the histology, into lupus glomerulitis and lupus glomerulonephritis. In lupus glomerulitis the LDH activity was slightly, but not significantly, less than that found in healthy kidneys. However, the LDH activity of proximal convolutions was increased significantly above normal, both in active $(t=4.4, \mathrm{p}=<0.01)$ and in healing lupus glomerulonephritis $(t=3.22, \mathrm{p}=<0.01)$. The activity in the distal convolutions was increased slightly above normal, but the differences were of questionable significance (active, $t=2.31$, $\mathrm{p}=<0.05$; healing, $t=2.15, \mathrm{p}=0.05)$. No differences were observed between the LDH activity in the nephron in active and in healing lupus glomerulonephritis.

From these data it will be noted that there were significant differences between the enzyme activities in lupus glomerulitis and lupus glomerulonephritis, and this was found for all units of the nephron analyzed. There was virtually no overlap between the activities found in these two groups (glomeruli, $t=4.26, \mathrm{p}=<0.001$; proximal convolutions, $t=6.34, \mathrm{p}=<0.001$; distal convolutions, $t=3.04, \mathrm{p}=<0.02$; medullary rays, $t$ $=3.16, \mathrm{p}=<0.02)$. An analysis of variance $(7)$ was also done in order to assess the significance of the variations within the three subgroups of lupus nephritis. This showed that the differences between the mean activities for the three groups, taking into account the individual variation within each group, were significant in the case of the glomeruli $(F=4.19, p=<0.05)$, highly significant in the case of the proximal convolutions $(\mathrm{F}=11.2, \mathrm{p}=<0.01)$, but not significant for the distal convolutions $(\mathrm{F}=2.85, \mathrm{p}=>0.05)$.

Effect of ischemia on enzyme activity. The data from one patient with healing lupus glomerulonephritis, studied on two occasions, are not included in Tables I and II. In addition to lupus nephritis an old thrombosis was present in the aorta of this patient, extending to the bifurcation and partially occluding the renal arteries. Histologically, there was evidence of patchy, severe ischemic changes in addition to the lesions of lupus glomerulonephritis. The enzyme activities in the glomeruli and convoluted tubules of this patient are given in Table III. In the nonischemic nephrons the levels of activity of both enzymes were comparable with those found in other cases of lupus glomerulonephritis, whereas extremely low enzyme activities were found in severely ischemic nephrons. 
TABLE III

Results of assay of alkaline phosphatase and lactic dehydrogenase activities in the nephrons from a patient with healing lupus glomerulonephritis and severe vascular ischemia (expressed in moles of substrate split per kilogram dry weight of tissue per hour at $37^{\circ} \mathrm{C}$ ) ${ }^{*}$

\begin{tabular}{|c|c|c|c|c|c|c|}
\hline \multirow[b]{2}{*}{ Structure analyzed } & \multicolumn{3}{|c|}{ Alkaline phosphatase } & \multicolumn{3}{|c|}{ Lactic dehydrogenase } \\
\hline & $\begin{array}{l}\text { Severely } \\
\text { ischemic } \\
\text { nephrons }\end{array}$ & $\begin{array}{l}\text { Completely } \\
\text { hyalinized } \\
\text { nephrons }\end{array}$ & $\begin{array}{l}\text { Nonischemic } \\
\text { nephrons }\end{array}$ & $\begin{array}{l}\text { Severely } \\
\text { ischemic } \\
\text { nephrons }\end{array}$ & $\begin{array}{l}\text { Completely } \\
\text { hyalinized } \\
\text { nephrons }\end{array}$ & $\begin{array}{l}\text { Nonischemic } \\
\text { nephrons }\end{array}$ \\
\hline Glomeruli & $\underset{[4]}{0.18} \underset{[4]}{ \pm 0.07}$ & $\underset{[11]}{0.14} \underset{[11}{0.05}$ & $\underset{[2]}{0.45 \underset{2}{ \pm} 0.38}$ & $\underset{[5]}{33.6} 13.8$ & $\underset{[6]}{8.03} \underset{1.71}{ \pm}$ & $132 \underset{[4]}{ \pm} 10.3$ \\
\hline Convoluted tubules & $\begin{array}{c}0.48 \pm 0.23 \\
{[16]}\end{array}$ & $0.34 \underset{[6]}{0} 0.105$ & $\begin{array}{c}3.26 \pm 0.29 \\
{[8]}\end{array}$ & $\begin{array}{c}60.0 \pm 9.1 \\
{[15]}\end{array}$ & & ${ }_{[12]}^{250 \pm 16.1}$ \\
\hline
\end{tabular}

* Results are expressed as means with standard error of the means, and the number of fragments analyzed is in brackets.

Variability of the observations. The coefficients of variation for alkaline phosphatase and LDH activities are shown in Table IV. The coefficient of variation between healthy individuals was smaller than that within healthy individuals, an observation which was also made in studies on normal animals $(5,6)$. The same was true for lupus nephritis. The variation of alkaline phosphatase activity within individuals with lupus nephritis was greater than within healthy kidneys. The variation in LDH activity from nephron to nephron was similar to that found in the normal. The average variation from kidney to kidney within each histological subgroup of lupus nephritis was somewhat greater in the case of alkaline phosphatase activity than the variation from healthy kidney to healthy kidney. No such difference was found in the case of LDH activity.

Effect of prednisone on enzyme activity. Most of the renal biopsies assayed were taken from pa- tients who were being treated with prednisone. The patients with healing lupus glomerulonephritis were receiving an average dose of $50 \mathrm{mg}$ prednisone daily, whereas most of those with lupus glomerulitis and with active lupus glomerulonephritis had not been treated with steroid hormones or drugs, or were being treated with lower doses of prednisone (approximately 15 to $20 \mathrm{mg}$ per day). In order to examine the effects of prednisone on the enzyme activity of the nephron, an experiment was done on rats. Renal biopsies were taken from four adult Sprague-Dawley rats, weighing an average of $327 \mathrm{~g}$. Each rat was then injected intramuscularly with prednisolone, $1 \mathrm{mg}$ daily, for 14 days, and was then sacrificed. Enzyme assays were made on the glomeruli and on the proximal and distal convolutions of the tubules from the biopsy and autopsy specimens of the same rat. The results are shown in Table V. It is evident that prednisolone in this dosage-

TABLE IV

Coefficient of variation for alkaline phosphatase and lactic dehydrogenase activity in healthy kidneys and in kidneys from patients with lupus nephritis

\begin{tabular}{|c|c|c|c|c|c|c|c|c|}
\hline \multirow[b]{3}{*}{$\begin{array}{r}\text { Structure } \\
\text { analyzed }\end{array}$} & \multicolumn{4}{|c|}{ Alkaline phosphatase } & \multicolumn{4}{|c|}{ Lactic dehydrogenase } \\
\hline & \multicolumn{2}{|c|}{ Healthy kidneys } & \multicolumn{2}{|c|}{ Lupus nephritis } & \multicolumn{2}{|c|}{ Healthy kidneys } & \multicolumn{2}{|c|}{ Lupus nephritis } \\
\hline & $\begin{array}{c}\text { Coefficient } \\
\text { of variation } \\
\text { within } \\
\text { individuals* }\end{array}$ & $\begin{array}{l}\text { Coefficient } \\
\text { of variation } \\
\text { between } \\
\text { individuals }\end{array}$ & $\begin{array}{c}\text { Coefficient } \\
\text { of variation } \\
\text { within } \\
\text { individuals }\end{array}$ & $\begin{array}{l}\text { Coefficient } \\
\text { of variation } \\
\text { between } \\
\text { individuals } \\
\text { within } \\
\text { each group }\end{array}$ & $\begin{array}{l}\text { Coefficient } \\
\text { of variation } \\
\text { within } \\
\text { individuals }\end{array}$ & $\begin{array}{l}\text { Coefficient } \\
\text { of variation } \\
\text { between } \\
\text { individuals }\end{array}$ & $\begin{array}{c}\text { Coefficient } \\
\text { of variation } \\
\text { within } \\
\text { individuals }\end{array}$ & $\begin{array}{c}\text { Coefficient } \\
\text { of variation } \\
\text { between } \\
\text { individuals } \\
\text { within } \\
\text { each group }\end{array}$ \\
\hline Glomeruli & $\begin{array}{c}65.3 \\
(42.9-100)\end{array}$ & 35.4 & $\begin{array}{c}76.6 \\
(18-165)\end{array}$ & 48.3 & $\begin{array}{c}31.9 \\
(17.9-53.6)\end{array}$ & 20.4 & $\begin{array}{c}21.5 \\
(6-48)\end{array}$ & 19.7 \\
\hline $\begin{array}{l}\text { Proximal } \\
\text { convolutions }\end{array}$ & $\begin{array}{c}28.1 \\
(16.4-36.0)\end{array}$ & 15.8 & $\begin{array}{c}48.3 \\
(13-92)\end{array}$ & 25.6 & $\begin{array}{c}20.4 \\
(8.4-34.4)\end{array}$ & 15.9 & $\begin{array}{c}18.6 \\
(8-34)\end{array}$ & 15.3 \\
\hline $\begin{array}{l}\text { Distal } \\
\quad \text { convolutions }\end{array}$ & $\begin{array}{c}48.8 \\
(28.1-65.2)\end{array}$ & 18.5 & $\begin{array}{c}62.1 \\
(23-113)\end{array}$ & 53.0 & $\begin{array}{c}21.9 \\
(12.0-36.9)\end{array}$ & 17.4 & $\begin{array}{c}27.3 \\
(12-46)\end{array}$ & 26.7 \\
\hline
\end{tabular}

\footnotetext{
* The range is given in parentheses.
} 
TABLE $\mathrm{V}$

The effect of prednisolone, $1 \mathrm{mg}$ daily for 14 days, on alkaline phosphatase and lactic dehydrogenase activity in the individual anatomical units of nephrons of the rat *

\begin{tabular}{|c|c|c|c|c|c|c|c|c|}
\hline \multirow[b]{2}{*}{$\begin{array}{l}\text { Structure } \\
\text { analyzed }\end{array}$} & \multicolumn{2}{|c|}{ Rat 1} & \multicolumn{2}{|c|}{ Rat 2} & \multicolumn{2}{|c|}{ Rat 3} & \multicolumn{2}{|c|}{ Rat 4} \\
\hline & $\begin{array}{c}\text { Before } \\
\text { prednisolone }\end{array}$ & $\begin{array}{c}\text { After } \\
\text { prednisolone }\end{array}$ & $\begin{array}{c}\text { Before } \\
\text { prednisolone }\end{array}$ & $\begin{array}{c}\text { After } \\
\text { prednisolone }\end{array}$ & $\begin{array}{c}\text { Before } \\
\text { prednisolone }\end{array}$ & $\begin{array}{c}\text { After } \\
\text { prednisolone }\end{array}$ & $\begin{array}{c}\text { Before } \\
\text { prednisolone }\end{array}$ & $\begin{array}{c}\text { After } \\
\text { prednisolone }\end{array}$ \\
\hline & \multicolumn{8}{|c|}{ Alkaline phosphatase } \\
\hline Glomeruli & $\begin{array}{c}2.66 \pm 0.56 \\
{[7]}\end{array}$ & $\begin{array}{c}2.41 \pm 0.11 \\
{[6]}\end{array}$ & $\begin{array}{c}5.12 \pm 0.81 \\
{[8]}\end{array}$ & $\begin{array}{c}3.98 \pm 1.08 \\
{[11]}\end{array}$ & $\begin{array}{c}1.54 \pm 0.40 \\
{[6]}\end{array}$ & $\begin{array}{c}2.04 \pm 0.23 \\
{[6]}\end{array}$ & $\begin{array}{c}4.02 \pm 0.89 \\
{[6]}\end{array}$ & $\begin{array}{c}3.70 \pm 0.69 \\
{[5]}\end{array}$ \\
\hline $\begin{array}{l}\text { Proximal } \\
\text { convolutions }\end{array}$ & $\begin{array}{c}21.6 \pm 1.87 \\
{[13]}\end{array}$ & $\begin{array}{c}15.8 \pm 1.46 \\
{[7]}\end{array}$ & $\begin{array}{c}24.2 \pm 2.09 \\
{[10]}\end{array}$ & $\begin{array}{c}21.6 \pm 1.72 \\
{[6]}\end{array}$ & $\begin{array}{c}8.11 \pm 0.91 \\
{[7]}\end{array}$ & $\begin{array}{c}9.47 \pm 1.10 \\
{[6]}\end{array}$ & $\begin{array}{c}19.7 \pm 1.16 \\
{[7]}\end{array}$ & $\begin{array}{c}23.3 \pm 2.84 \\
{[8]}\end{array}$ \\
\hline \multirow[t]{2}{*}{$\begin{array}{l}\text { Distal } \\
\text { convolutions }\end{array}$} & $\begin{array}{c}1.51 \pm 0.51 \\
{[6]}\end{array}$ & $\begin{array}{c}2.39 \pm 0.42 \\
{[7]}\end{array}$ & $\begin{array}{c}1.86 \pm 0.61 \\
{[12]}\end{array}$ & $\begin{array}{c}1.74 \pm 0.52 \\
{[13]}\end{array}$ & $\begin{array}{c}1.52 \pm 0.29 \\
{[5]}\end{array}$ & $\begin{array}{c}1.78 \pm 0.40 \\
{[7]}\end{array}$ & $\begin{array}{c}1.81 \pm 1.24 \\
{[7]}\end{array}$ & $\begin{array}{c}2.61 \pm 0.75 \\
{[7]}\end{array}$ \\
\hline & \multicolumn{8}{|c|}{ Lactic dehydrogenase } \\
\hline Glomeruli & $\begin{array}{c}76.7 \pm 3.27 \\
{[6]}\end{array}$ & $\begin{array}{c}83.5 \pm 6.50 \\
{[6]}\end{array}$ & $\begin{array}{c}77.3 \pm 4.78 \\
{[6]}\end{array}$ & $\begin{array}{c}70.8 \pm 11.7 \\
{[5]}\end{array}$ & $\begin{array}{c}78.0 \pm 12.1 \\
{[7]}\end{array}$ & $\begin{array}{c}78.0 \pm 0.74 \\
{[6]}\end{array}$ & $\begin{array}{c}77.3 \pm 8.45 \\
{[7]}\end{array}$ & $\begin{array}{c}71.5 \pm 19.5 \\
{[5]}\end{array}$ \\
\hline $\begin{array}{l}\text { Proximal } \\
\text { convolutions }\end{array}$ & $\begin{array}{c}128 \pm 12.2 \\
{[12]}\end{array}$ & $\begin{array}{c}115 \pm 6.44 \\
{[12]}\end{array}$ & $\begin{array}{c}160 \pm 8.45 \\
{[7]}\end{array}$ & $\begin{array}{c}137 \pm 14.0 \\
{[5]}\end{array}$ & $\begin{array}{c}119 \pm 4.65 \\
{[7]}\end{array}$ & $\begin{array}{c}134 \pm 7.94 \\
{[6]}\end{array}$ & $\begin{array}{c}112 \pm 13.7 \\
{[7]}\end{array}$ & $\begin{array}{c}132 \pm 13.5 \\
{[6]}\end{array}$ \\
\hline $\begin{array}{l}\text { Distal } \\
\text { convolutions }\end{array}$ & $\begin{array}{c}364 \pm 36.2 \\
{[5]}\end{array}$ & $\begin{array}{c}268 \pm 35.4 \\
{[7]}\end{array}$ & $\begin{array}{c}350 \pm 36.4 \\
{[6]}\end{array}$ & $\begin{array}{c}342 \pm 21.8 \\
{[6]}\end{array}$ & $\begin{array}{c}297 \pm 7.96 \\
{[5]}\end{array}$ & $\begin{array}{c}389 \pm 16.8 \\
{[7]}\end{array}$ & $\underset{[7]}{330 \pm 26.2}$ & $\begin{array}{c}285 \pm 52.3 \\
{[5]}\end{array}$ \\
\hline
\end{tabular}

* Results, expressed in MKH units, are means with standard errors. The number of fragments of tissue analyzed is given in brackets.

which, on a weight for weight basis, is approximately four times that used in the patients-had no significant or consistent effect on the enzyme activity of the glomeruli or convoluted tubules.

The weights, diameters and derived densities of the glomeruli from healthy kidneys and from kidneys with lupus nephritis are given in Table VI. The impression that glomeruli of lupus nephritis were heavier than glomeruli from healthy kidneys was confirmed; they were 40 per cent heavier than those of healthy kidneys and the difference was significant statistically $(t=3.6, \mathrm{p}=<0.01)$. The heaviest glomeruli were found in the group with active lupus glomerulonephritis. The diameter of the glomeruli was increased significantly only in the group with active lupus glomerulonephritis $(t$ $=3.28, \mathrm{p}=<0.01)$. The density index of the glomeruli

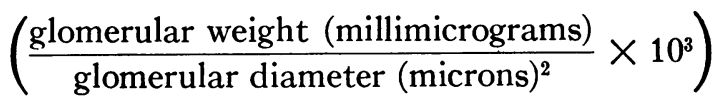

was somewhat increased in lupus nephritis, as compared to the normal, but this difference was not statistically significant $(t=2.01, \mathrm{p}=>0.05)$. The greatest density was found in healing lupus glomerulonephritis.

TABLE VI

The weights, diameters and density of glomeruli from healthy kidneys and from kidneys of patients with lupus nephritis*

\begin{tabular}{|c|c|c|c|c|c|}
\hline \multirow[t]{2}{*}{ - } & \multirow[b]{2}{*}{ Healthy kidneys } & \multirow[b]{2}{*}{ Lupus glomerulitis } & \multicolumn{2}{|c|}{ Lupus glomerulonephritis } & \multirow{2}{*}{$\begin{array}{l}\text { All lupus } \\
\text { nephritis }\end{array}$} \\
\hline & & & Active & Healing & \\
\hline Glomerular weight $(\mathrm{m} \mu \mathrm{g})$ & $\underset{9 \dagger[130]}{42.1 \pm 7.81}$ & $\underset{5}{56.8} \stackrel{131]}{ \pm}$ & $\underset{5}{66.5} \stackrel{18.62}{[82]}$ & $\underset{7}{55.9} \underset{[101]}{ \pm 17.30}$ & $\begin{array}{cc}59.3 & \pm 16.49 \\
17 & {[234]}\end{array}$ \\
\hline Glomerular diameter $(\mu)$ & $\underset{g}{179.8} \underset{[90]}{ \pm 16.4}$ & $\underset{5}{196.0} \underset{[50]}{ \pm}$ & $\underset{5}{204.5} \underset{[50]}{ \pm 11.6}$ & $\underset{7}{179.6} \underset{[70]}{ \pm 10.6}$ & $\begin{array}{c}191.7 \\
17\end{array}$ \\
\hline Glomerular density $\ddagger$ & $\underset{g}{1.32 \pm} 0.29$ & $\underset{5}{1.57 \pm 0.66}$ & $1.59 \pm 0.41$ & $\frac{1.75 \pm}{7} 0.65$ & $1.65 \pm \frac{1}{17} 0.55$ \\
\hline
\end{tabular}

* Values are expressed as means with standard deviations of the means for each kidney. Total number of glomeruli analyzed is given in brackets.

† Number of kidneys analyzed is given in italic type.

$\ddagger$ The density index of the glomeruli $=\frac{\text { glomerular weight }}{\text { glomerular diameter }{ }^{2}} \times 10^{3}$. 


\section{DISCUSSION}

Alkaline phosphatase activity was found to be decreased in the proximal and distal convolutions of the tubules in patients with lupus nephritis, but the level of enzyme activity was not related to the presence or severity of morphologic changes in the tubules. The alkaline phosphatase activity of the glomeruli was within normal limits, and there were no apparent effects of glomerular damage of varying severity on the level of enzyme activity found. The coefficient of variation of alkaline phosphatase activity from nephron to nephron in the same kidney was greater for lupus nephritis than for healthy kidneys. However, this was almost certainly due, at least in part, to technical artifact, particularly in the abnormal kidneys analyzed, for alkaline phosphatase activities in them were close to those of the blanks $(3,5)$.

By contrast, LDH activity was decreased slightly, but not to a significant degree, only in lupus glomerulitis; whereas there was a slight but statistically significant increase in the activity of this enzyme in the glomeruli and throughout the tubules in lupus glomerulonephritis. The differences between enzyme activity in lupus glomerulitis and lupus glomerulonephritis were statistically significant in the glomeruli and proximal convolutions of the tubules. Thus, there was an inverse relationship between LDH activity and histological evidence of degeneration of the proximal and distal convolutions.

These differences were not related to the presence or degree of renal functional impairment: in lupus glomerulonephritis the average specific gravity concentration was 1.020 ; the average creatinine clearance was $76 \mathrm{ml}$ per minute; the average urea clearance was 56 per cent of average normal renal function; and the average phenolsulfonphthalein excretion in 15 minutes was 28 per cent. None of these patients excreted excess glucose, phosphate or amino acids in the urine.

The differences in LDH activity did not appear to be related to the dosage of prednisone used to treat these patients. The patients with healing lupus glomerulonephritis were receiving large doses of prednisone, whereas both those with lupus glomerulitis and those with active lupus glomerulonephritis were untreated, or were being treated with small doses of prednisone. Moreover, no significant or consistent effect on enzyme activity was observed when prednisolone was injected into rats.

Glomerular damage in lupus nephritis precedes the appearance of significant structural changes in the convoluted tubules. The morphologic changes in the glomeruli may be very severe before definite tubular damage is evident-in this respect, lupus nephritis differs from many other renal diseases such as glomerulonephritis and pyelonephritis. This could result in a physiological situation in which the renal tubules, particularly the proximal convolutions, perform increased work in reabsorbing from the tubular lumens substances such as protein filtered in excess by the glomeruli, or in excreting other substances into the tubular lumens. Thus, the relative increase in $\mathrm{LDH}$ activity in lupus glomerulonephritis might be an enzymatic expression of the preserved function of these tubules and of their ability to respond metabolically to increased metabolic demands. By contrast, in primary renal tubular diseases, the LDH activity of the convoluted tubules was normal in the presence of mild tubular abnormalities and was significantly decreased when the tubules were severely damaged (3). The view that the tubules in lupus glomerulonephritis are capable of responding to increased metabolic demands would be consistent with the hypothesis of Platt, namely, that in chronic renal disease residual functioning nephrons may be capable of normal activities and even of functional adaptations which may result in an increase of work done per residual functioning nephron (8). The view of Platt has gained considerable support from the studies of Bricker, Morrin and Kime on the adaptive changes in residual nephrons of dogs with experimenal unilateral renal disease (9). Their investigations strongly suggest that the surviving nephrons in diseased kidneys function normally, and that specific functional sites are not selectively destroyed in different nephrons, a condition which would result in great functional differences from nephron to nephron.

In our studies the coefficient of variation of $\mathrm{LDH}$ activity from nephron to nephron in the same kidney was similar for healthy kidneys and for lupus nephritis (Table IV), suggesting that the nephron population examined in lupus nephritis was as homogenous with respect to $\mathrm{LDH}$ ac- 
tivity as was the nephron population of healthy kidneys. The only exception to this was in the case of grossly ischemic and probably nonfunctioning nephrons (Table III) in which the LDH activity was extremely low.

The relationship between the histology of the glomeruli and their weight, diameter and density. In lupus nephritis fibrinoid and hyaline materials are deposited on the endothelial surface of the glomerular basement membrane, and there is frequently an increase of both endothelial and epithelial cells. A wide variety of other changes also occurs in the glomeruli (2). The finding that the weight of glomeruli was 40 per cent greater in lupus nephritis than in healthy kidneys was consistent with these histological observations. The most severe and most widespread histological changes were seen in active lupus glomerulonephritis, in which condition the glomeruli were heaviest, and were found to have the greatest diameter. The densest glomeruli, however, were found in healing lupus glomerulonephritis. In healing lupus glomerulonephritis the active glomerular lesions had almost entirely disappeared, leaving glomeruli which had a diffusely thickened basement membrane as the major lesion. These glomeruli did not look large histologically, and their diameter was similar to that of healthy glomeruli, but their density was greater than that of healthy glomeruli and of glomeruli in both the other groups of lupus nephritis. This was consistent with the finding of diffuse capillary basement membrane thickening.

\section{SUMMARY}

1. Alkaline phosphatase and lactic dehydrogenase (LDH) activities were measured in the individual anatomic units of the nephron in 18 biopsy and one autopsy specimen from 13 patients with lupus nephritis.

2. Alkaline phosphatase activity was considerably less than normal in the proximal and distal convolutions of the tubules in lupus glomerulitis and in lupus glomerulonephritis.

3. $\mathrm{LDH}$ activity was increased in lupus glomerulonephritis but not in lupus glomerulitis. The variation of $\mathrm{LDH}$ activity from nephron to nephron was no greater in lupus nephritis than in healthy kidneys. In this respect the diseased nephrons were as homogenous as healthy nephrons.

4. The weights of 130 glomeruli from healthy kidneys and of 234 glomeruli from kidneys affected by lupus nephritis were measured. The glomeruli in lupus nephritis were found to be 40 per cent heavier than those from healthy kidneys, and scarred, healed glomeruli were found to be denser than those in which the disease was active.

\section{ACKNOWLEDGMENTS}

We wish to thank Dr. Conrad L. Pirani for his invaluable help with the renal pathology. The technical assistance of Mrs. Hendrina deBruin, Miss Alta D. Tsoodle and Mr. Bart R. Mayron is gratefully acknowledged. The prednisone used to treat these patients was supplied by the Schering Corporation, Bloomfield, N. J., through the courtesy of Dr. C. Szmal.

\section{REFERENCES}

1. Muehrcke, R. C., Kark, R. M., Pirani, C. L., and Pollak, V. E. Lupus nephritis: A clinical and pathologic study based on renal biopsies. Medicine (Baltimore) 1957, 36, 1.

2. Pollak, V. E. Lupus nephritis: The effect of large doses of prednisone on the progression of the disease in Proceedings of the Eleventh Annual Conference on the Nephrotic Syndrome. New York, National Kidney Disease Foundation, 1960. In press.

3. Pollak, V. E., Bonting, S. L., Muehrcke, R. C., and Kark, R. M. Quantitative histochemistry of the nephron. IV. Alkaline phosphatase and lactic dehydrogenase activities in renal tubular diseases. J. clin. Invest. 1960, 39, 1386.

4. Kark, R. M., and Muehrcke, R. C. Biopsy of kidney in prone position. Lancet 1954, 1, 1047.

5. Bonting, S. L., Pollak, V. E., Muehrcke, R. C., and Kark, R. M. Quantitative histochemistry of the nephron. II. Alkaline phosphatase activity in man and other species. J. clin. Invest. 1960, 39, 1372.

6. Bonting, S. L., Muehrcke, R. C., Pollak, V. E., and Kark, R. M. Quantitative histochemistry of the nephron. III. Lactic dehydrogenase activity in man and other species. J. clin. Invest. 1960, 39, 1381.

7. Snedecor, G. W. Statistical Methods Applied to Experiments in Agriculture and Biology, 4th ed. Ames, Iowa, Iowa State College Press, 1946, chap. 10.

8. Platt, R. Structural and functional adaptation in renal failure. Brit. med. J. 1952, 1, 1313, 1372.

9. Bricker, N. S., Morrin, P. A. F., and Kime, S. W., Jr. The pathologic physiology of chronic Bright's disease. An exposition of the "intact nephron hypothesis." Amer. J. Med. 1960, 28, 77. 